\title{
An unusual presentation of an uncommon disease
}

This article was published in the following Dove Press journal:

International Journal of General Medicine

24 November 2009

Number of times this article has been viewed

\author{
Michael Funk ${ }^{2}$ \\ Orlando Santana ${ }^{1,2}$ \\ 'Department of Cardiology, \\ ${ }^{2}$ Mt. Sinai Medical Center, Miami \\ Beach, FL USA
}

Correspondence: Orlando Santana Director, Department of Cardiology, Mt. Sinai Medical Center, 4300 Alton Road, Miami Beach, FI 33I40, USA Email osantana@msmc.com

\begin{abstract}
Extrapulmonary manifestations of sarcoidosis often go undiagnosed. Sarcoidosis should be considered in the differential diagnosis of cases presenting with parotid gland swelling, renal failure, and hypercalcemia. It's imperative to confirm the diagnosis with a tissue biopsy, as the condition is easily treatable with steroids.
\end{abstract}

Keywords: sarcoidosis, parotid gland, renal failure, hypercalcemia, steroids

\section{Case report}

We report a 56-year-old white female who developed progressively worsening bilateral parotid swelling with bilateral ear pain for three months. She was given a prolonged course of antibiotics to treat parotitis, without improvement. She had no other symptoms.

Her physical examination demonstrated bilateral symmetric parotid gland swelling with no evidence of lymphadenopathy. The parotid glands were warm and tender to palpation. The lungs were clear to auscultation. There was normal S1 and S2 without murmurs. The neurological examination failed to reveal any deficits. The cranial nerves were intact. There were no motor or sensory deficits. Reflexes were $2+$ in all extremities. The abdomen was benign. The extremities were without clubbing, cyanosis, or edema. Pulses were intact and the strength was $5 / 5$ in all extremities with full range of motion.

The laboratory values on admission are listed on the table shown. Three months prior to admission, her baseline creatinine was 0.8 . A renal ultrasound showed increased echogenicity of the bilateral cortices. A chest X-ray was normal (Figure 1). A gallium scan was performed which showed increased uptake in the parotid glands, salivary glands, thyroid gland, and kidneys at 72 hours (Figure 2). A computed axial tomography (CT scan) of the chest was also normal.

Because of her hypercalcemia and renal dysfunction, she was administered intravenous fluids. There was no improvement in her renal function. She had a good urine output, but after several days her renal function declined further. A renal biopsy was then performed, showing acute and chronic tubulointerstitial nephritis with numerous noncaseating granulomas making the diagnosis of sarcoidosis (Figure 3 ). The pathology specimen was AFB negative, and the patient was PPD negative, making the diagnosis of tuberculosis unlikely. She had no increased eosinophils in the peripheral smear to suggest a drug-related interstitial nephritis, and antineutrophil cytoplasmic antibodies (ANCA) levels were negative, ruling out Wegener's granulomatosis. In our patient, a renal biopsy was done instead of a parotid or salivary gland biopsy, because her CT 


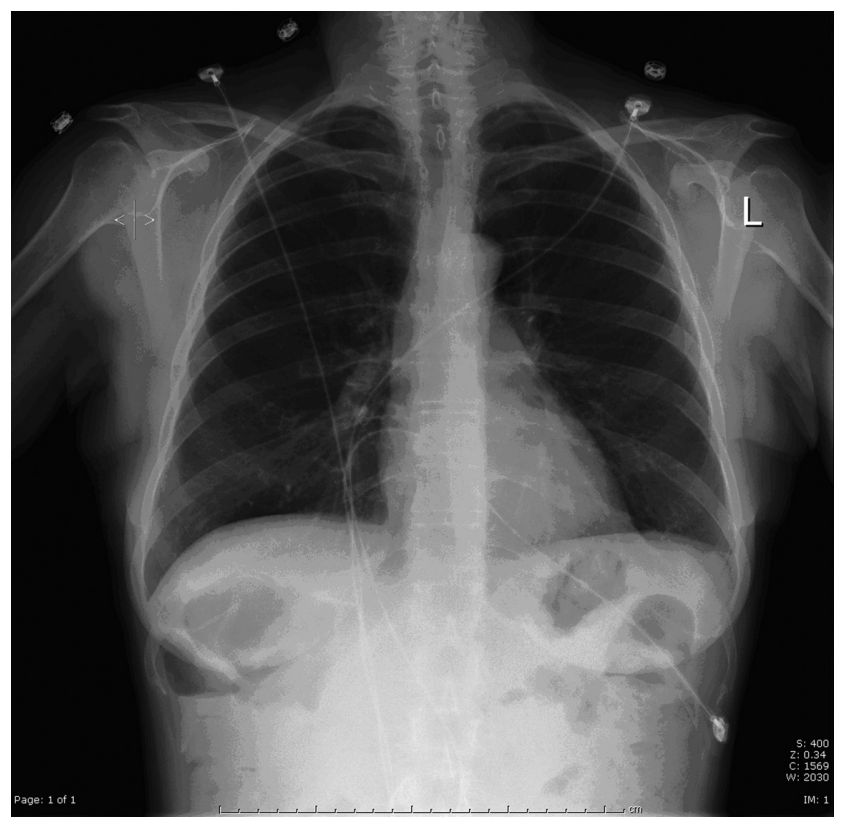

Figure I Normal chest X-ray.

scan of the chest was normal, and we had a low index of suspicion for sarcoidosis.

She was started on prednisone $1 \mathrm{mg} / \mathrm{kg}$ orally per day. Over the following two weeks, her renal dysfunction improved, her symptoms resolved, and the calcium level returned to normal levels.

\section{Discussion}

Sarcoidosis is a chronic systemic disorder of unknown etiology characterized by noncaseating granulomas infiltrating multiple organs. The lungs and lymph nodes are the predominant sites affected, but other organs may also be involved such as the kidneys, liver, spleen, and bone marrow. Parotid gland swelling has been reported in $4 \%$ to $6 \%$ of patients with sarcoidosis. ${ }^{1,2}$

The diagnosis of sarcoidosis can be made by in up to $71 \%$ of the cases by performing a salivary gland biopsy. Biopsies of the parotid and salivary glands are simple and noninvasive, yet they are not used systematically. This is probably because physicians tend not associate parotid swelling with systemic sarcoidosis. Published case reports of bilateral parotid gland swelling and renal failure as the presentation of sarcoidosis are rare. ${ }^{3}$ There are a few reported cases with rapidly progressive loss of renal function that may be attributable to granulomatous interstitial nephritis. ${ }^{4}$ Renal involvement without pulmonary involvement is exceedingly rare. ${ }^{5,6}$ The administration of corticosteroids improves renal function, help with the hypercalcemia, and also alleviate the symptoms.

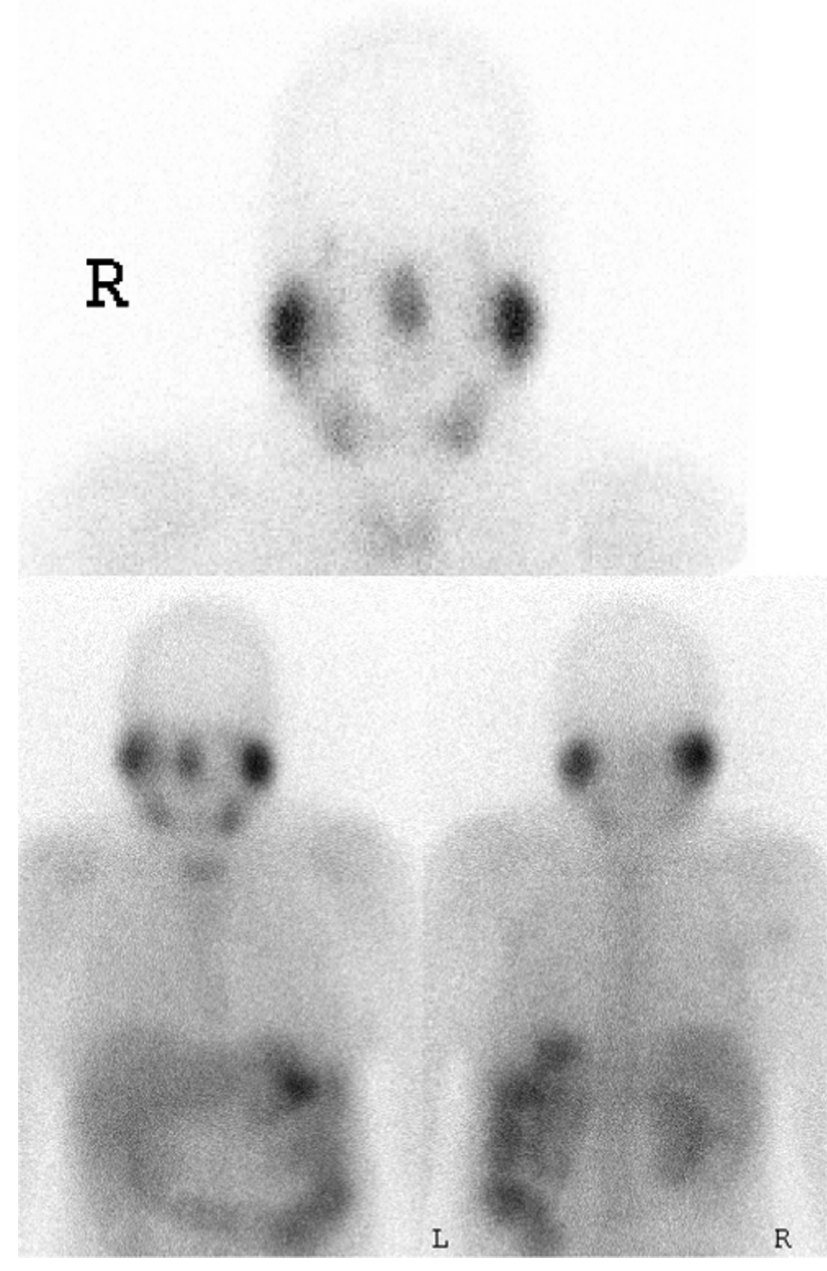

Figure 2 A Gallium scan showing increased uptake in the parotid glands, salivary glands, thyroid gland, and kidneys at 72 hours.

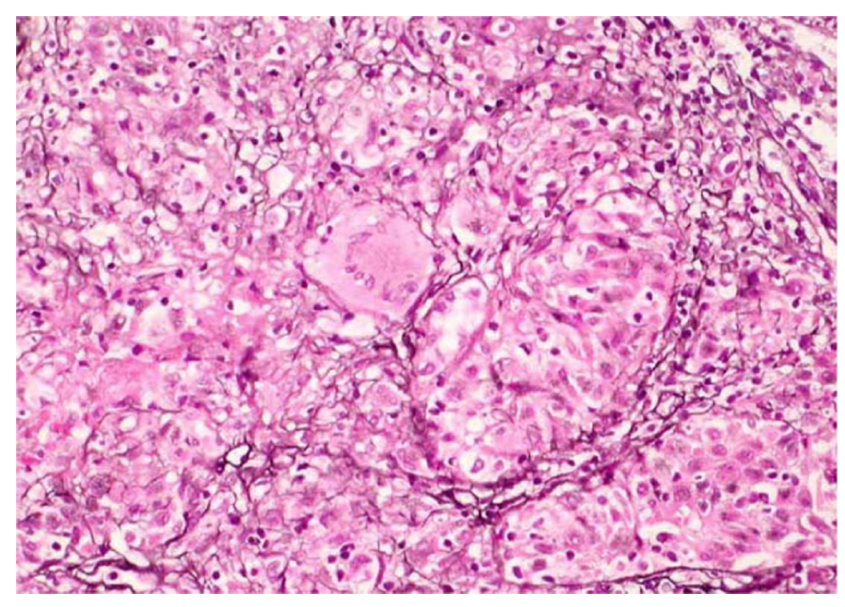

Figure 3 Left renal parenchymal biopsy showing tubulointerstitial nephritis with noncaseating granulomas. 
Table I Laboratory data

\begin{tabular}{ll}
\hline WBC & 9,000 \\
Hemoglobin & $9.5 \mathrm{~g} / \mathrm{dL}$ \\
Hematocrit & $28 \%$ \\
Platelets & 466,000 \\
Bun & $28 \mathrm{mg} / \mathrm{dL}$ \\
Creatinine & $2.6 \mathrm{mg} / \mathrm{dL}$ \\
PTH & $5 \mathrm{I} \mathrm{pg} / \mathrm{ml}(\mathrm{I0-55)}$ reference \\
HIV & Negative \\
25 -hydroxycholecalciferol & $25 \mathrm{ng} / \mathrm{ml}$ \\
TSH & $2.5 \mathrm{mlU} / \mathrm{L}$ \\
ESR & $93 \mathrm{~mm} / \mathrm{hr}$ \\
CRP & $3.4 I$ \\
ANA & Negative \\
Sjogren's antibodies & Negative \\
Rheumatoid factor & Negative \\
SPEP & Normal \\
UPEP & Normal \\
Hepatitis panel & Negative \\
ACE level & $75 \mathrm{U} / \mathrm{L}(23-57)$ reference \\
Liver function tests & Normal \\
Corrected calcium & $\mathrm{II} .1 \mathrm{mg} / \mathrm{dL}$ \\
24 hour urinanalysis & $350 \mathrm{mg}$ protein \\
\hline
\end{tabular}

Abbreviations: ACE, angiotensin-converting enzyme; ANA, antinuclear antibodies; CRP, C-reactive protein; ESR, erythrocyte sedimentation rate; HIV, human immunodeficiency virus; PTH, pituary thyroid hormone; SPEP, serum protein electrophoresis; TSH, thyroid-stimulating hormone; UPEP, urine protein electrophoresis; WBC, white blood cells.

Gallium imaging is a useful tool for evaluation of areas of activity in extrapulmonary sarcoidosis, and has a sensitivity of $97 \%$. It is an excellent indicator of therapeutic efficacy and becomes negative after steroid therapy in most cases. ${ }^{7}$

Recognition of extrapulmonary sarcoidosis can be challenging. Physicians should be aware of this entity as early diagnosis, and treatment with steroids is beneficial. ${ }^{8}$

\section{Disclosures}

The authors report no conflicts of interest in this work.

\section{References}

1. Uddin MA, Riaz M, Bhatti MA. Parotid gland sarcoidosis with renal failure. J Coll Phys Surg Pak. 2005;15:441-442.

2. James DG, Sharma OP. Parotid gland sarcoidosis. Sarcoidosis Vasc Diffuse Lung Dis. 2000;17:27-32.

3. Mitome J, Kawaguchi Y, Arase H, et al. A case of renal sarcoidosis. Clin Exp Nephrol. 2004;8:375-379.

4. Miyoshi K, Okura T, Manabe S, et al. Granulomatous interstitial nephritis due to isolated renal sarcoidosis. Clin Exp Nephrol. 2004;3:279-282.

5. Brause M, Magnusson K, Degenhardt S, Helmchen U, Grabensee B. Renal involvement in sarcoidosis - a report of 6 cases. Clin Nephrol. 2002;57(2):142-148.

6. Ponce C, Gujral JS. Renal failure and hypercalcemia as initial manifestations of extrapulmonary sarcoidosis. South Med J. 2004;97:590-592.

7. Ziessman HA. Infection and inflammation. Nuclear Medicine: The Requisites, 1st Ed. St. Louis, MO: Mosby; 1995.

8. Jayawardene SA, Pattison JM. An elderly man with confusion, hypercalcemia, and acute renal failure-an important diagnosis not to miss. Nephrol Dial Transplant. 2000;15:1468-1470.
International Journal of General Medicine

\section{Publish your work in this journal}

The International Journal of General Medicine is an international, peer-reviewed open-access journal that focuses on general and internal medicine, pathogenesis, epidemiology, diagnosis, monitoring and treatment protocols. The journal is characterized by the rapid reporting of reviews, original research and clinical studies across all disease areas.

\section{Dovepress}

A key focus is the elucidation of disease processes and management protocols resulting in improved outcomes for the patient. The manuscript management system is completely online and includes a very quick and fair peer-review system. Visit http://www.dovepress.com/ testimonials.php to read real quotes from published authors. 